\title{
The Extension of TAM Model in the Use of Point of Sale (Pos) in Minimarkets in Padang, Indonesia
}

Yuhelmi, Mery Trianita, and Surya Dharma

Lecturers at University of Bung Hatta

\section{Abstract}

The use of information technology system in the form of Point of Sale (POS) becomes essential in assisting operational minimarket. The purpose of this study is to extend the original TAM model to investigate factors affecting the behavior of Point of Sales (POS) users. Information quality of POS and subjective norm is conceptualized as an external variable that affects POS acceptance through perceived usefulness and perceived ease of use. The number of respondents who participated in this study was 270 employees of minimarket in Padang. The results show that the quality of information positively

Corresponding Author:

Yuhelmi

yuhelmi@bunghatta.ac.id

Received: 18 January 2019 Accepted: 24 March 2019 Published: 31 March 2019

Publishing services provided by Knowledge E

(c) Yuhelmi et al. This article is distributed under the terms of the Creative Commons

Attribution License, which permits unrestricted use and redistribution provided that the original author and source are credited.

Selection and Peer-review under the responsibility of the First ELEHIC Conference Committee.

\section{G OPEN ACCESS} affects subjective norms, perceived usefulness and attitude, as well as subjective norms positively affect perceived ease of use, perceived usefulness and attitude. Perceived usefulness mediates the full perceived ease of use effect on attitude. Lastly, attitude has a positive effect on actual use. The results of this study show that the quality of relevant and accurate information and opinions of colleagues are taken into consideration for employees in using POS.

Keywords: Information Quality, Point of Sale, Subjective Norm, TAM

\section{Introduction}

Minimarkets in the city of Padang, West Sumatra, experienced rapid growth marked by the existence of several new minimarket establishments (e.g., Minang Mart, Daya Mart, X Mart and MM 88) by opening outlets at several points of location. The growth of minimarket makes information system technology becomes important in order to improve service to consumer and assist company operational to work faster and more accurate to minimize human error [1]. Computer-based POS is an essential information technology system needed in minimarkets. Point of Sale (POS) is one form of combining Hardware and Software that forms a system to facilitate transactions with customers, record inventory, find out sales reports and profits per day, weekly, monthly even annually. POS initially is a cash register which is a sort of calculator machine with a cash 
drawer and proof of purchase, receipt or invoice [2]. Along with the development and advancement of technology, cash register function cannot meet the needs for businesses that require detail income statement, stock of goods, and other needs. POS media requires several devices, such as PC / Computer or laptop, Cashier Printer, Cash Drawer, Barcode Scanner, Pole display, MSR (Magnetic Stripe Reader) and Software [2].

Minimarkets in Padang in average utilize POS with complete devices, but in practice, it is found that this system has not been used optimally [3]. In traditional minimarkets, the use of POS is only to help make transactions quickly whereas the identification for movement of goods is slow. The speed of inventory turnover, debt and receivables, profitability, the remaining stock available on the shelf / warehouse is only obtained from experience so that the accuracy of the data is uncertain. POS should produce this information so that it can be used in decision making. The low utilization of information used by the user becomes important to investigate the cause. Is the quality of information generated through POS inaccurate, not timely or irrelevant? Does the owner or manager, coworkers or organization not support the use of POS?. [4] developed a model of technological acceptance that is a useful behavioral model for answering why information technology systems fail to be applied. This study aims to investigate the effect of information quality and subjective norms on actual use through perceived ease of use, perceived usefulness and attitude that is an extension of the Technology Acceptance Model (TAM) model. This study tries to anticipate the weaknesses of the TAM model by taking respondents as real technology users and using subjects from various organizations managed with different management so that the results can be generalized [5].

\section{Literature Review}

\subsection{Technology acceptance model}

Technology Acceptance Model (TAM) was developed by $[4,6]$ which is the theory of information systems concerning with the technology acceptance model for users [7]. This model adopts the Theory of Reasoned Action (TRA) developed by [8]. TAM is a behavioral model built with strong theory and has been tested by many researchers and the results largely support the TAM model, therefore it is concluded that TAM is a powerful model [9]. The TAM model (Figure 1) is a model of parsimony that is a simple model (using only perceived ease of use and perceived usefulness [10, 11] but valid [12]. [4] found that perceived ease of use has a strong impact on Intention behavior and less 
impact on Attitude so that [12] issued Attitude variables from a model called TAM 1 as shown in Figure 2.

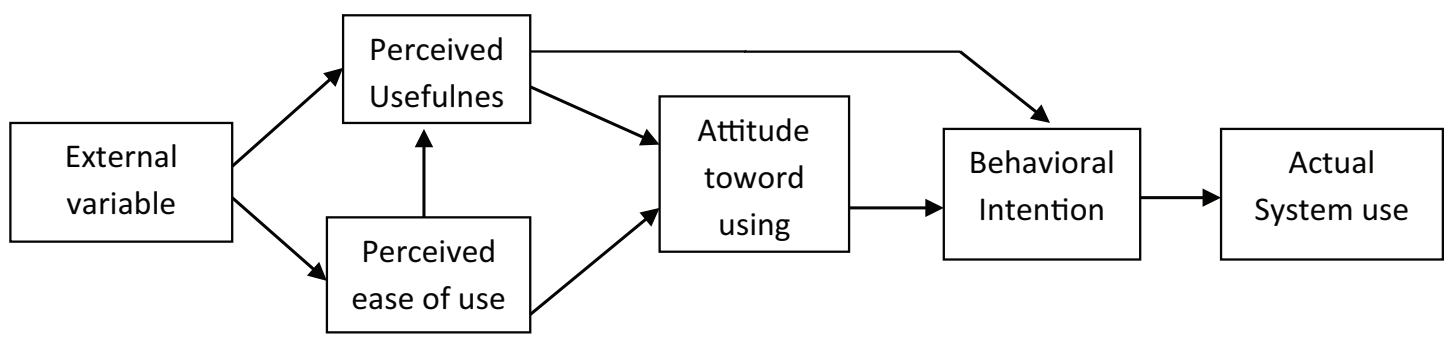

Figure 1: Technology Acceptance Model Source: Davis et al (1989).

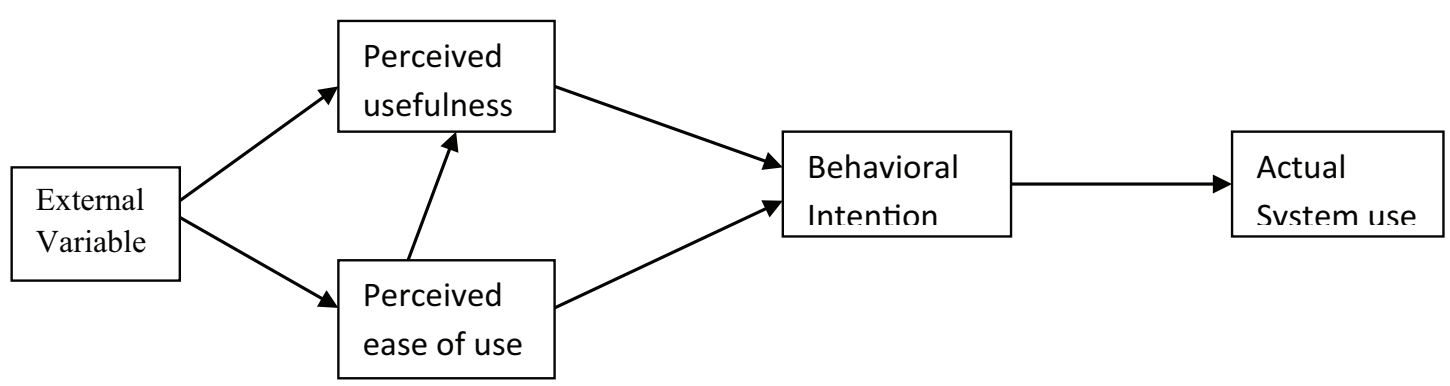

Figure 2: Technolology Acceptance Model (TAM) 1 Source: Venkates and Davis (1996).

The TAM model called TAM 2 by [13] was expanded by adding five external variables (Subjective norm, image, job relevance, output quality and result demonstrability) that influence behavior intention through perceived usefulness and 2 moderating variables (Experience and Voluntariness). Lastly, [14] extended a more complete TAM model called TAM 3 by adding variable 4, variable Anchor (Computer Self Efficacy, Perception of External Control, Computer Anxiety and computer Playfulness) and 2 adjustment variables (Perceived Enjoyment and Objective Usability) and 2 variables moderating (experience and voluntariness). The TAM 3 model is a combination of the TAM 2 model with the model proposed by [15].

\section{Research Model}

The proposed research model is an extension of the original TAM model by taking information quality and subjective norms into models that affect actual use through perceived ease of use, perceived usefulness and attitude. The research model can be seen in Figure 3. 


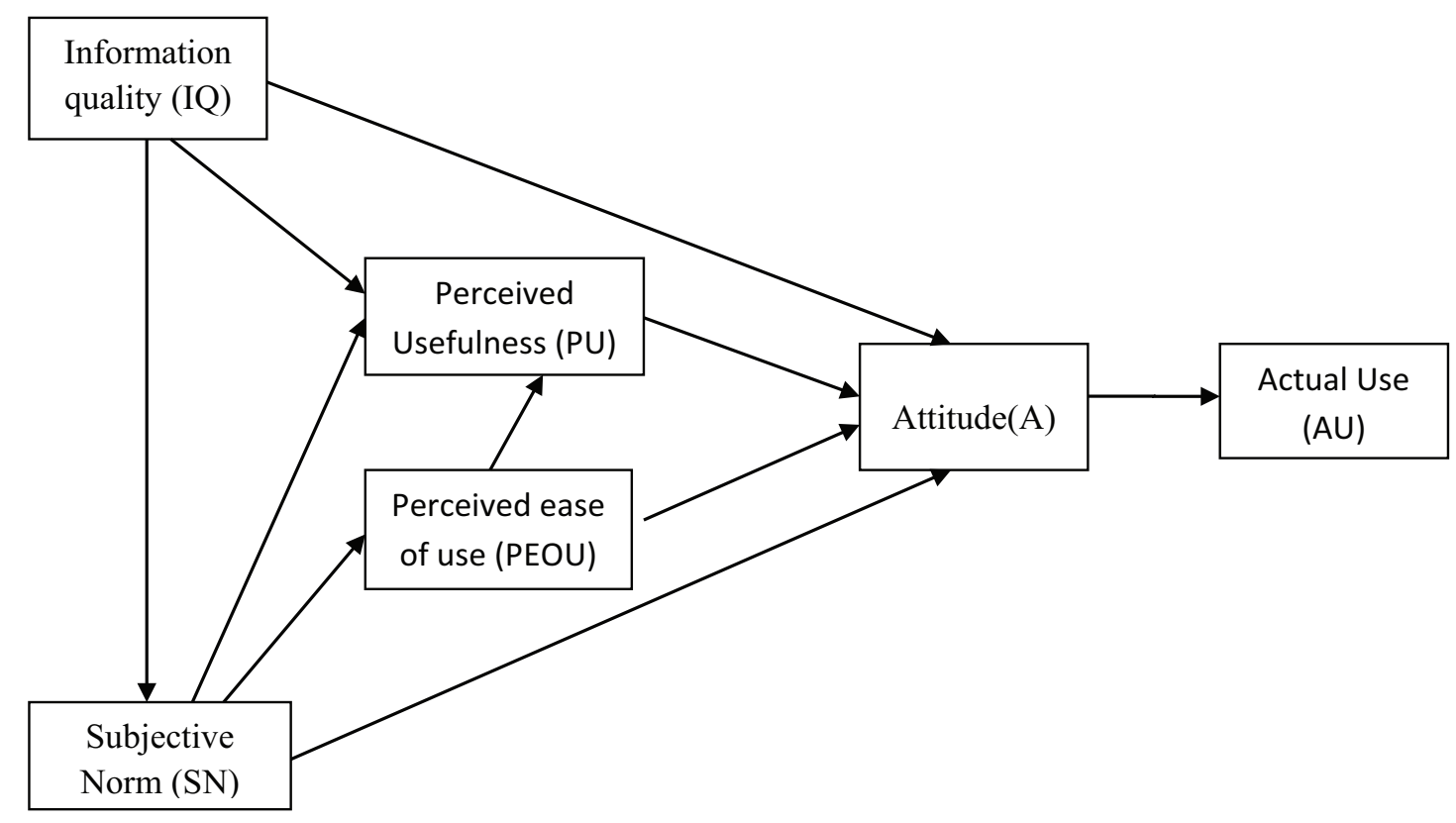

Figure 3: Research Model.

\subsection{The influence of information quality on subjective norm, perceived usefulness dan attitude}

According to [16], Information is data that has been processed into a form that is useful and has value for decision making now and in the future. According to [17] Information quality is the quality of information features accuracy, timeliness, completeness, relevance, and consistency meanwhile, according to [1] Information quality is measured by Reliability, Comparability and Relevancy. Perceived information quality affects perceived usefulness, perceived ease of use and attitude [18]. The better the quality of information received by users of information systems, where the information received is relevant to the needs, the accuracy of the level is trusted, the information received complete and clear, exactly the time required and consistent, the higher perceived usefulness for the user in improving its performance [13]. In addition, the higher the quality of information received by people is important as peer opinion, the more helpful it is for users to behave to receive technology information systems. Consequently, the following hypothesis can be formulated as follow:

H1: Information quality has positive effects on subjective norms

$\mathrm{H}$ 2: Information quality has positive effects on perceived usefulness

H3: Information quality has positive effects on attitude 


\subsection{The influence of subjective norm on perceived ease of use, perceived usefulness and attitude}

Subjective norm is a person's perception or view on other people's beliefs that will influence the behavior being considered [8]. Subjective norms play an important role in influencing someone to behave. Theory of Reason Action (TRA) identifies that subjective norms and attitudes are two determinants of behavior intention [8]. Furthermore, Theory of Planned Behavior (TPB), which is a continuation model of TRA, also includes subjective norm as a factor considered in the acceptance of information technology $[19,20]$ states that social influence (similar to subjective norms) such as family and friends will influence the behavior of user interest. [21] found that subjective norms positively affect perceived ease of use and attitude. While $[15,22,23]$ found that subjective norms positively affect perceived usefulness. $[24,25]$ found a positive norm of positive falling against Attitude. Based on previous research, the following hypothesis can be proposed:

H4: Subjective norm has a positive effect on perceived ease of use

H5: Subjective norm has a positive effect on perceived usefulness

H6: Subjective norm has a positive effect on Attitude

\subsection{The influence of perceived ease of use on perceived useful- ness dan attitude}

Perceived ease of use is defined to the extent that a person believes that using a technology will be free of effort [4]. This definition explains that if a person believes that the use of information systems technology is easy, then he or she will feel that the technology is useful and will accept the use of the technology. Conversely, if the use of technology is not easy, then he or she does not feel the usefulness of the technology so he or she will not use it. [21, 25-29] conducted research for the use of different technologies, finding that perceived ease of use influences perceived usefulness and attitude whereas Premkumar and [10, 30, 31] found perceived ease of use has an effect on perceived usefulness. [32] found perceived ease of use had an effect on Attitude. Based on the explanation, thus the hypothesis can be explained as follow:

H7: Perceived ease of use has positive effects on perceived usefulness

H8: Perceived ease of use has a positive effect on attitude 


\subsection{The influence of perceived usefulnes on attitude}

Perceived usefulness is defined to what extent one believes that using a technology will improve its performance [4]. If someone considers that using a technology in the work will be useful (because it can improve efficiency, effectivity and quality of work, and facilitate work), then he or she will use the technology. [22, 24, 25, 28, 33-35] found in their research that perceived usefulness has positive effect on Attitude. The proposed hypothesis is:

H9: Perceived usefulness has a positive effect on Attitude

\subsection{The influence of attitudeon actual use}

Attitude is defined as a positive or negative feeling of a person when it comes to performing the behavior to be determined [4]. If someone believes that the use of information technology can really help him or her in his work, then he or she will use the technology (positive feelings), on the contrary if someone feels that the technology he will use will not help him, then he will not use the technology (negative feelings). [28, 30, 35, 36] found that attitude has a positive effect on actual use, so the hypothesis proposed is;

H10: Attitude has a positive effect on actual use

\section{Methods}

The population in this study is employees of minimarket located in the city of Padang, Indonesia. Sampling used purposive sampling with criteria employee working assisted with Computer based Point of Sale (POS) program. The data used are primary data by distributing 5-point linkert-scale questionnaires from strongly disagree to strongly agree [37]. Questionnaires were distributed through the manager or head of the minimarket store which was the object of research. The number of questionnaires distributed was as many as 286 and returned as many as 277 . After being evaluated, the complete and feasible questionnaires used in this study were only 270 .

Before further testing steps, it is necessary to test Discriminant Validity and Reliability for variable measurement instruments. The value of discriminant validity is a cross loading value of a useful factor to find out whether the construct has adequate discriminant that is by comparing the loading value in the intended construct must be greater than the loading value with another construct. Discriminant validity uses Principal Components 
TABLE 1: Rotated factor loadings.

\begin{tabular}{|c|c|c|c|c|c|c|}
\hline Variable & Factor1 & Factor2 & Factor3 & Factor4 & Factor5 & Factor6 \\
\hline IQ1 & 0.1650 & 0.2270 & 0.0571 & 0.6827 & 0.2739 & 0.1211 \\
\hline IQ2 & 0.2134 & 0.2725 & 0.2680 & 0.7352 & 0.0703 & 0.0856 \\
\hline IQ3 & 0.1846 & 0.1495 & 0.2206 & 0.7039 & 0.2042 & 0.2722 \\
\hline IQ4 & 0.1246 & -0.0331 & 0.1905 & 0.7111 & 0.2767 & 0.3137 \\
\hline SN1 & 0.1432 & 0.1671 & 0.1320 & 0.1664 & 0.1676 & 0.6724 \\
\hline SN2 & 0.0981 & 0.1468 & 0.2541 & 0.1839 & 0.2111 & 0.6852 \\
\hline SN3 & 0.1845 & 0.2564 & 0.2260 & 0.3411 & 0.0606 & 0.5428 \\
\hline PEOU1 & 0.7200 & -0.0676 & 0.2950 & 0.1025 & 0.0686 & 0.1237 \\
\hline PEOU2 & 0.5700 & 0.2296 & 0.2975 & 0.1461 & -0.1147 & 0.1505 \\
\hline PEOU3 & 0.5527 & 0.2192 & 0.3839 & 0.0895 & 0.0181 & 0.0299 \\
\hline PEOU4 & 0.5224 & 0.3513 & 0.3266 & 0.1213 & 0.0382 & 0.1050 \\
\hline PEOU5 & 0.6823 & 0.1973 & 0.0215 & 0.0203 & 0.0792 & 0.1056 \\
\hline PEOU6 & 0.7445 & 0.1866 & -0.0178 & 0.1764 & 0.2550 & 0.0151 \\
\hline PEOU7 & 0.7476 & 0.1876 & -0.0126 & 0.2423 & 0.0690 & 0.0657 \\
\hline PU1 & 0.0326 & 0.7504 & 0.0945 & -0.0117 & 0.1554 & 0.1894 \\
\hline PU2 & 0.1984 & 0.6758 & 0.3402 & 0.0958 & 0.0529 & 0.1140 \\
\hline PU3 & 0.3127 & 0.5476 & 0.3508 & 0.3368 & 0.0306 & 0.1489 \\
\hline PU4 & 0.1819 & 0.6302 & 0.3221 & 0.3189 & 0.0837 & 0.0941 \\
\hline PU5 & 0.2575 & 0.5271 & 0.1230 & 0.3777 & 0.1705 & 0.1091 \\
\hline PU6 & 0.1604 & 0.5493 & 0.2374 & 0.1468 & 0.2218 & 0.2729 \\
\hline $\mathrm{A} 1$ & 0.1549 & 0.2545 & 0.6067 & 0.3786 & 0.1975 & -0.0637 \\
\hline A2 & 0.1851 & 0.3391 & 0.6446 & 0.1962 & 0.0795 & 0.2715 \\
\hline A3 & 0.1520 & 0.1710 & 0.6309 & 0.2452 & 0.1939 & 0.3039 \\
\hline A4 & 0.1228 & 0.2926 & 0.6375 & 0.0949 & 0.1749 & 0.3137 \\
\hline A5 & 0.1914 & 0.2337 & 0.6479 & 0.1095 & 0.2650 & 0.1837 \\
\hline AU1 & 0.0017 & 0.3872 & 0.1426 & 0.2259 & 0.5616 & 0.2685 \\
\hline AU2 & 0.1604 & 0.3905 & 0.2212 & 0.1739 & 0.6046 & -0.0198 \\
\hline AU3 & 0.1063 & -0.1303 & 0.2929 & 0.1953 & 0.5179 & -0.1665 \\
\hline AU4 & 0.1335 & 0.0963 & 0.2063 & 0.1150 & 0.6729 & 0.3309 \\
\hline AU5 & 0.0087 & 0.1056 & -0.0186 & 0.1730 & 0.7011 & 0.2853 \\
\hline
\end{tabular}

with varimax rotation. A construct is considered valid if Factor Loading is greater than 0.5. Table 1 shows that the loading factor value of each construct using the STATA 12 program is obtained above 0.5 . This result indicates that each item forming a construct 
is eligible and valid while the reliability test used was Croanbach Alpha. The construct is said to be reliable if it has a large Croanbach Alpha of 0.7 [37]. From the results, it was found that the instruments are reliable as shown in table 2.

TABLE 2: Reliability Testing.

Variable
Subjective Norm (SN)
Information Quality (IQ)
Perceived ease of use (PEOU)
Perceived usefulness (PU)
Attitude (A)
Actual Use (AU)

Croanbach's Alpha
0.8639
0.8596
0.8776
0.8491
0.8504
0.8719

\begin{tabular}{|c|}
\hline Result \\
\hline Reliable \\
\hline Reliable \\
\hline Reliable \\
\hline Reliable \\
\hline Reliable \\
\hline Reliable \\
\hline
\end{tabular}

\section{Results and Discussion}

The results of path analysis with the STATA 12 program can be seen in table 3 . Information quality was found to have a positive effect on the subjective norm with 0.58 path coefficient and $p$ value $<0.001$, so hypothesis 1 was concluded. These results indicate that the better the quality of information generated from POS in supporting the work done by employees, the stronger the influence on colleagues, managers and organizations in using POS. This result shows that information quality is the main factor in increasing the role of peer opinion to influence attitude and actual use. Information Quality was also found to positively affect perceived usefulness with coefficient path 0.23 and $p$ value $<0.001$. Therefore, the second hypothesis can be accepted. These results indicate that the more accurate and relevant the information generated from the POS information system, the more likely it will be felt to use POS usage in improving performance. It was also found that information quality positively influence attitude with path coefficient 0.20 and $p$ value $<0.001$, therefore the $3 r d$ hypothesis can be accepted. These results indicate that user attitudes are determined by accurate and relevant information quality obtained from the use of POS. Thus it can be concluded that Information Quality becomes the main factor in increasing the role of peer opinion and is considered in the technology acceptance model either through subjective norm or attitude. This result is strengthened from the results of $[13,38]$ that quality information affects the use of information systems so as to benefit from the use of such systems. If the POS information system can provide more accurate and relevant information to the work done, the stronger the motivation 
of colleagues and the employer in using POS and will be felt useful in improving their performance, which will ultimately affect the attitude and use of the information system.

TABle 3: The Result of Path Analysis.

\begin{tabular}{l|c|c|c}
\hline The Hypotesis & $\begin{array}{c}\text { Path } \\
\text { coefficient }\end{array}$ & P Value & Support \\
\hline H1: Information Quality $\rightarrow$ Subjective Norm & 0.58 & 0,000 & Yes \\
\hline H2: Information Quality $\rightarrow$ Perceived usefulness & 0.23 & 0.000 & Yes \\
\hline H3: Information Quality $\rightarrow$ Attitude & 0,20 & 0,000 & Yes \\
\hline H4: Subjective Norm $\rightarrow$ Perceived ease of use & 0.43 & 0.000 & Yes \\
\hline H5: Subjective Norm $\rightarrow$ Perceived usefulness & 0,30 & 0.000 & Yes \\
\hline H6: Subjective Norm $\rightarrow$ Attitude & 0.22 & 0.000 & Yes \\
\hline H7: Perceived ease of use $\rightarrow$ Perceived usefulness & 0,40 & 0.000 & Yes \\
\hline H8: Perceived ease of use $\rightarrow$ Attitude & 0.10 & 0,060 & No \\
\hline H9: Perceived Usefulness $\rightarrow$ Attitude & 0,40 & 0,000 & Yes \\
\hline H10; Attitude $\rightarrow$ Actual Use & 0,56 & 0,000 & Yes \\
\hline
\end{tabular}

The 4th hypothesis in this study proved that subjective norms positively influence perceived ease of use with 0.43 path coefficient and $p$ value $<0.001$. These results indicate that the stronger the encouragement of colleagues, superiors and the organization as a whole, the use of POS will be considered easier, because colleagues or superiors participate in providing assistance if there are difficulties in using POS. But if the manager or colleagues do not care about the use of POS, the user feels difficult to operate the POS and ultimately reluctant to use POS. As a result, the investment made by the minimarket owner has become inefficient and effective. This study also found that subjective norms positively affect perceived usefulness with coefficient path 0.30 and $p$ value $<0.001$, so that the 5 th hypothesis is accepted. These results indicate that the stronger the encouragement of colleagues, superiors and organizations to use POS, the more useful the POS will be in improving its performance. This result is consistent with the results of previous studies [13, 22. 23], where subjective norms affect perceived usefulness. Subjective norms were also found to positively influence attitude with path coefficient 0.22 and $p$ value $<0.001$, so the 6 th hypothesis is acceptable. The more the role of peers, superiors and organizations against the use of POS, will affect the attitude of users in receiving information systems. These results are consistent with previous research $[21,24,25]$. It can be concluded that the role of 'opinions' determines actual use through perceived ease of use, perceived usefulness and attitude. 
This study also found that perceived ease of use has a positive effect on perceived usefulness with coefficient path 0.40 and $p$ value $<0.001$, meaning that the 7 th hypothesis is acceptable. These results are consistent with the findings of $[3,4,22,28,29,31$, $39,40]$ However the results of this study found that perceived ease of use had no direct effect on Attitude with $p$ value $>0.05$, therefore, the 8th hypothesis was rejected. The absence of the perceived ease of use influence on attitude is caused by respondents who used it more is working as a cashier, who likes it or not must be able to operate the computer-based POS, so that the attitude towards the use of POS does not depend on ease of use but is a factor of compulsion. Most of the computer-based information systems (POSs) designed by information systems developers, are easier to operate with simple steps. It is also caused by a tool in the form of tagging or scanner price reader of a product, so the tool helps the user in using POS because it does not affect the perceived ease of use towards Attitude. The perceived ease of use does not mediate the subjective norm's influence on Attitude, while subjective norms directly affect Attitude. This result is inconsistent with research findings [21, 24, 25], but supported by [41] with decomposed TPB and [42] models for experienced user groups.

The 9th hypothesis about the effect of perceived usefulness on Attitude was found to positively affect the path coefficient 0.4 and $p$ value $<0.001$. These results are consistent with the results of a previous study of $[3,4,21,22,26-28,30,35]$, [43] These results indicate if the use of POS is able to improve their performance then they will behave by using the POS in the work. The final attitude proved to have significant effect on actual use with path coefficient 0.56 and $p$ value $<0.001$, which means the 10th hypothesis is acceptable. This result shows that Actual use is determined by user attitude. If users behavior is to receive information technology, then they will use it in the works. This result is consistent with the results of the researchers $[28,30,35,36]$.

\section{Conclussion and Recommendations}

The objective of this research is to expand the TAM model developed by $[4,5]$ by conceptualizing information quality $[1,38]$ and subjective norms $[21,24]$ in influencing the actual use of POS in minimarket. Based on the result of the research, quality and subjective norms are factors that are considered in the use of POS that are mediated by perceived ease of use, perceived usefulness and attitude. To improve the quality of information it is advisable for minimarket owners to choose experienced POS developers so that the built system output produces quality information (that is relevant to the user's work, the resulting information is complete, accurate and in accordance with the 
decision-making needs), therefore the POS that is built must be easier to use and has functions that can improve performance, productivity, facilitate work, and make work more attractive. The role of employees, managers and organization (subjective norm) is also important in the acceptance of POS. It is suggested that the manager or owner can improve the communication relationship both vertically and horizontally in order to create a culture of mutual help in the work. In addition, it is necessary to apply participatory management style so that subordinates feel more attention in carrying out the task, resulting in the formation of a solid and effective Team work.

Future research is expected to expand this basic TAM model by adding external variables that have not yet included into this research model such as Perceived enjoyment, perceived behavioral control, experience and moderation variables such as gender, age, education and skills using various software. Experienced users will commonly tend to be faster to accept the use of technology than the less experienced. This is because being experience makes one accustomed to using sophisticated technology. This also applies to the level of education. Highly educated users will prefer to work using a better information system than a lowly educated. This is due to the high awareness of highly educated people for the use of more sophisticated technology however this opinion needs to be proven through research in the future research.

\section{References}

[1] Zadeh, M. H. K., Karkon, A., \& Golnari, H. (2013). The Effect of Information Technology on the Quality of Accounting Information. Shiraz Journal of System Management, 3(3), 61-76.

[2] Utami, C. W. (2010). Manajemen ritel (2nd ed.). Jakarta: Salemba Empat.

[3] Yuhelmi., Dharma, S., Trianita, M., \& Mulatsih, L. S. (2018). The Determinants of User Behavior of Computer Based Transaction Processing Systems: The Case of Minimarket Employees in Padang, Indonesia. International Journal of Engineering \& Technology, 7(4(9)), 90-95.

[4] Davis, F. D. (1989). Perceived Usefulness, Perceived Ease Of Use, And User Accep. MIS Quarterly, 13(3), 319

[5] Jogiyanto, 2007. Sistem Informasi Keperilakuan,. Edisi Revisi. Yogyakarta: Andi Offset

[6] Davis, F. D., Bagozzi, R. P., \& Warshaw, P. R. (1989). User Acceptance of Computer Technology: a Comparison of Two Theoretical Models *. Management Science, 35(8), 982-1003. 
[7] Fan, C.-W. (2014). Applied the Technology Acceptance Model to Survey the mobilelearning adoption behavior in Science Museum. International Journal of Innovation and Scientific Research, 12(1), 22-29.

[8] Fishbein, M. \& Ajzen, I. (1975). Belief, attitude, attitude, intention and behavior: An introduction to theory of research. Reading, MA: Addison-Wesley Addison-Wesley, 578.

[9] Lin, F., Fofanah, S. S., \& Liang, D. (2011). Assessing citizen adoption of e-Government initiatives in Gambia: A validation of the technology acceptance model in information systems success. Government Information Quarterly, 28(2), 271-279.

[10] Gao, L., \& Bai, X. (2014). A unified perspective on the factors influencing consumer acceptance of internet of things technology, 26(2), 211-231.

[11] Alambaigi, A., \& Ahangari, I. (2015). Technology Acceptance Model (TAM) As a Predictor Model for Explaining Agricultural Experts Behavior in Acceptance of ICT. International Journal of Agricultural Management and Development (IJAMAD), 6(2), 235-247.

[12] Venkatesh, V., \& Davis, F. D. (1996). A Model of the Antecedents of Perceived Ease of Use: Development and Test. Decision Science, 27(3), 451-481.

[13] Venkatesh, Viswanath., Davis, F. D. (2000). Theoretical Acceptance Extension Model: Field Four Studies of the Technology Longitudinal. Management Science, 46(2), 186 204.

[14] Venkatesh Viswanath; Bala, H. (2008). Technology Acceptance Model 3 and a Research Agenda on Interventions. Decision Sciences, 39(2), 273-315.

[15] Venkatesh, V. (2000). Determinants of Perceived Ease of Use: Integrating Control, Intrinsic Motivation, and Emotion into the Technology Acceptance Model. Information Systems, 11(4), 342-365.

[16] Davis, G. B. (2000). Information systems conceptual foundations: looking backward and forward. Organizational and Social Perspectives on Information Technology IFIP - The International Federation for Information Processing, 41, 61-82.

[17] Delone, W. H., \& Mclean, E. R. (2004). Measuring e-Commerce Success: Applying the DeLone \& McLean Information Systems Success Model Value of Information Technology in e-Business Environments (Fall, 2004), International Journal of Electronic Commerce, 9(1) pp. 31-47., 31-47.

[18] Shih, H. P. (2004). An empirical study on predicting user acceptance of e-shopping on the Web. Information and Management, 41(3), 351-368.

[19] Ajzen, I. (1991). The theory of planned behavior. Organizational Behavior and Human Decession Processes, 50, 179-211. 
[20] Venkatesh, V., Thong, J. Y. L., \& Xu, X. (2012). Consumer Acceptance And Use of Information Technology: Extending The Unified Theory of Acceptance and Use of Technology. Forthcoming in MIS Quarterly, Vol. 36, No. 1 (2012), Pp. 157-178, 36(1), 157-178.

[21] Bashir, I., \& Madhavaiah, C. (2015). Consumer attitude and behavioural intention towards Internet banking adoption in India. Journal of Indian Business Research, 7(1), 67-102.

[22] Wu, B., \& Chen, X. (2016). Continuance intention to use MOOCs: Integrating the technology acceptance model (TAM) and task technology fit (TTF) model. Computers in Human Behavior, 67, 221-232.

[23] Yi, M. Y., Jackson, J. D., Park, J. S., \& Probst, J. C. (2006). Understanding information technology acceptance by individual professionals: Toward an integrative view. Information and Management, 43(3), 350-363.

[24] Dwivedi, Y. K., Rana, N. P., Jeyaraj, A., Clement, M., \& Williams, M. D. (2017). Reexamining the Unified Theory of Acceptance and Use of Technology (UTAUT): Towards a Revised Theoretical Model. Information Systems Frontiers, 1-16.

[25] Schierz, P. G., Schilke, O., \& Wirtz, B. W. (2010). Understanding consumer acceptance of mobile payment services: An empirical analysis. Electronic Commerce Research and Applications, 9(3), 209-216.

[26]. Agarwal, R., \& Prasad, J. (1999). Are individual differences germane to the acceptance of new information technologies? Decision Sciences, 30(2), 361-391

[27] Darsono, L. I. (2005). Examining Information Technology Acceptance by Individual Professionals. Gadjah Mada International Journal of Business, 7(2), 155-178.

[28] Nagy, J. T. (2018). Evaluation of Online Video Usage and Learning Satisfaction: An Extension of the Technology Acceptance Model. The International Review of Research in Open and Distributed Learning, 19(1), 160-184.

[29] Shipps, B., \& Phillips, B. (2013). Social Networks, Interactivity and Satisfaction: Assessing Socio-Technical Behavioral Factors as an Extension to Technology Acceptance. Journal of Theoretical and Applied Electronic Commrce Research, 8(1), $35-52$

[30] Bhattacherjee, A., \& Sanford, C. (2006). Influence Processes For Information Technology Acceptance: An Elaboration Likelihood Model 1. MIS Quarterly, 30(4), 805-825.

[31] Cheng, Y. M. (2015). Towards an understanding of the factors affecting m-learning acceptance: Roles of technological characteristics and compatibility. Asia Pacific Management Review, 1-11 
[32] Chen, H., Rong, W., Ma, X., Qu, Y., \& Xiong, Z. (2017). An Extended Technology Acceptance Model for Mobile Social Gaming Service Popularity Analysis. Hindawi Mobile Information Systems, 2017, 1-13.

[33] Chau, P. Y. K., \& Hu, P. J.-H. (2001). Information Technology Acceptance by Individual Professionals: A Model Comparison Approach. Decision Sciences, 32(4), 699-719.

[34] Alsamydai, M. J. (2014). Adaptation of the Technology Acceptance Model (TAM) to the Use of Mobile Banking Services. International Review of Management and Business Research, 3(4), 2016-2028.

[35] Fathema, N., Shannon, D., \& Ross, M. (2015). Expanding The Technology Acceptance Model (TAM) to Examine Faculty Use of Learning Management Systems (LMSs) In Higher Education Institutions. MERLOT Journal of Online Learning and Teaching, 11(2), 210-232.

[36] Al-Gahtani, S. S., \& King, M. (1999). Attitudes, satisfaction and usage: Factors contributing to each in the acceptance of information technology. Behaviour and Information Technology, 18(4), 277-297.

[37] Hair, J. F., Black, W. C., Babin, B. J., \& Anderson, R. E. (2010). In Multivariate Data Analysis (Seventh Ed, p. 761). Harlow, United Kingdom: Pearson Education Limited.

[38] DeLone, W. H., \& Mclean, E. R. (2003). The DeLone and McLean Model of Information Systems Success. Journal of Management Information Systems, 19(4), 9-30.

[39] Natarajan, T., Balasubramanian, S. A., \& Kasilingam, D. L. (2017). Understanding the intention to use mobile shopping applications and its influence on price sensitivity. Journalof Retailing and Consumer Services, 37, 8-22.

[40] Yakasai, A. B. M., \& Jusoh, W. J. W. (2015). Testing the Theory of Planned Behavior in Determining Intention to Use Digital Coupon among University Students. Procedia Economics and Finance, 31(15), 186-193.

[41] Taylor, S., \& Todd, P. (1995a). Assessing IT Usage: The Role of Prior Experience. MIS Quarterly, 19(4), 561-570

[42] Taylor, S., \& Todd, P. A. (1995b). Understanding information technology usage: A test of competing models. Information Systems Research. 6 (2), 144- 176 